\title{
Price, Design, and Quality of Products in Influencing the Decision to Purchase Cloth Masks During the Covid 19 Pandemic
}

Fendy Maradita ${ }^{1}$, Reza Muhammad Rizqi ${ }^{2}$, Gustiawan ${ }^{3}$

${ }^{123}$ Departement of Management, Sumbawa University of Technology, Indonesia

\begin{abstract}
Article Info

Volume 8, Issue 6

Page Number : 455-463

Publication Issue

November-December-2021

Article History

Accepted : 05 Dec 2021

Published : 16 Dec 2021

This study aims to test whether the price, design, and quality of products influence the decision to buy cloth masks during a pandemic. This research uses quantitative methods. The sample in this study amounted to 100 respondents obtained by non-probability sampling method with purposive sampling technique. The data obtained is processed using multiple linear analysis techniques through SPSS software. The results of the analysis in this study showed that (1) price variables have a positive and significant effect on purchasing decisions, (2) design variables have a positive and significant effect on purchasing decisions, (3) product quality variables have a positive and significant effect on purchasing decisions.
\end{abstract}

Keywords : Price, Design, Product Quality, Purchase Decision

\section{INTRODUCTION}

Corona Virus Disease or commonly called covid-19 is a disease infected by a virus that has just appeared to cause people around the world to be infected. The first covid-19 disease occurred in the Chinese city of Wuhan in December at the end of 2019. Covid-19 is a disease that can be transmitted from someone who has been infected which is the cause of acute respiratory syndrome coronavirus 2 or SARS-CoV-2 Since then it began to spread to other countries in other parts of the world to cause a global pandemic (Yuliana, 2020).

Pandemic is a disease phenomenon that attacks humans and is widespread in various countries and even continents. In early 2020, the term again grabbed the attention of the Indonesian people, with the emergence of the coronavirus disease outbreak or so-called covid-19 after its rapid and large-scale spread in many other countries such as China and Italy. The emergence of the first recorded cases in Indonesia since March 2, 2020, is very fast spreading and giving rise to many positive new cases exposed to covid-19, which causes panic and fear among the Indonesian people. (Santosa, 2020).

Responding to the social conditions that occur, the central government takes policies to deal with the spread of the Covid-19 virus in various ways. One of them is the call for activities at home and some health protocols that must be implemented in the face of this pandemic. Of course, with the Covid-19 pandemic, consumers need products that can prevent and protect 
themselves from the spread of Covid-19, including vitamin supplements, health drinks, masks, and hand sanitizers. Therefore, the use of masks and hand sanitizer is considered as an effort to reduce the risk of spreading the Covid-19 virus. (Santosa, 2020)

Masks serve to anticipate the spread of the coronavirus in Indonesia because they can filter air and filter harmful particles, the demand for masks in markets in Indonesia is increasing. For current needs, masks are an indispensable necessity during this pandemic. Masks commonly used by the public are cloth masks and face masks (disposable masks). But because of the high demand for masks, especially medical masks causes scarcity in the market, as an alternative cloth mask can be used by the public during activities facing the current health crisis (Ramadhanty, 2020).

Masks are much in demand by the public including cloth masks that are also widely used by the community. Especially after irresponsible parties hoard disposable masks amid the current pandemic. In addition, the World Health Organization (WHO) also encourages governments around the world to recommend non-medical masks for use by everyone in certain situations, especially during covid-19. With the implementation of health protocols such as the use of masks amid the covid-19 outbreak, few people are using the phenomenon as a business opportunity. (Ramadhanty, 2020).

The existence of this pandemic is used by some traders to see market opportunities, one of which is the high market demand for mask and hand sanitizer products. The number of products that have been created requires marketers as a party that offers consumers a variety of products to analyze the factors that are the basis of consumer behavior in making a shopping product. Covid-19 is a disaster for the whole world where this pandemic has a tremendous influence on all aspects around the world. Especially in terms of economic aspects experienced a very significant change since the covid-19 pandemic. In the pandemic period many goods and services experience price spikes in line with the surge in public demand, some products experience a surge in decline and there are even products that experience a surge in demand.

In this pandemic period, people prioritize their spending to buy products that are useful for selfprotection so as not to be exposed to the covid-19 virus. As Kotler and Armstrong (2013) found, price is the amount of money charged for a good or service or the amount of money a consumer exchanges for the benefits of owning or using that product or service.

Although many requests for the purchase of masks and hand sanitizers, it will affect the specified price. Nevertheless, although the price has increased related to mask products and hand sanitizers, the quality of the product also has a significant influence. According to Kotler at Pusparani and Rastini (2014), the higher the quality of the product, the higher the level of satisfaction felt by consumers, with the high satisfaction felt by consumers will recommend the product to others.

One strategy that can be used to attract consumers is the design of the product itself. Anandya (2015) added that product design distinguishes the product of a brand from other brands that create characteristics for a brand. It can be concluded that the product design is a feature contained in the product that distinguishes it from competitors' products. With the current events or circumstances, one of them is with an appeal to the community not to do activities outside the home and some health protocols that must be done during the covid-19 pandemic. The appeal was also implemented in every region throughout Indonesia including in Sumbawa Regency, West Nusa Tenggara. Currently, West Nusa Tenggara is included in the top 10 provinces with the most cases. One of them in Sumbawa Regency is currently in the red zone, especially in the city area, one of them is in Seketeng Village where the majority of the population works as traders and self-employed, for that the entire 
community in the seketeng village area is encouraged to oblige health protocols and not leave the house during the covid-19 pandemic.

Based on the background that has been outlined by researchers, the study is titled "PRICE, DESIGN, AND QUALITY OF PRODUCTS IN INFLUENCING THE DECISION TO PURCHASE CLOTH MASKS DURING PANDEMIC (case study on cloth mask users in Seketeng Village)

A. Price

According to Tjiptono (2012) price is a monetary unit or other measures (including other goods and services) exchanged to obtain ownership rights to the use of goods or services. This understanding is in line with the concept of exchange (exchange) in marketing.

According to Kotler and Armstrong (2012) that four measures characterize the price, namely:

1. Affordability of prices

2. Prices according to ability or price competitiveness

3. Price conformity with product quality

4. Price conformity with benefits

\section{B. Design}

Product design is a management tool that can translate the results of research and development activities carried out previously into special designs that will be produced and sold for profit. According to Kotler and Armstrong (2012) Design is at the heart of the product, Good design not only has a hand in the appearance of the product but also in its benefits. A well-designed product will win attention and sales. Good design can attract interest, improve product performance, reduce production costs and provide a strong competitive advantage to products within the target market.

According to Kotler and Keller in Soewito (2013) indicators of product design are as follows:
1. Product Color

2. Printing products

3. Form of product

4. The latest model

\section{Product Quality}

According to Kotler \&Armstrong (2014), product quality is everything that can be offered to the market to get attention, purchased, used, or consumed that can satisfy a desire or need. Consumers expect the quality offered by the manufacturer by the expectations that consumers want. Because, the better the quality of a product, the higher the desire of consumers in making repeated purchases. According to Akbar (2013), states indicators to measure product quality, namely:
1) Ease
2) Resilience
3) Function
4) Product diversity

\section{Purchasing Decision}

According to Setiadi, (2012) defining a decision involves the choice of two or more alternative actions or behaviors. Decisions always require a choice between several different behaviors. According to Kotler \& Armstrong (2012), purchasing decisions refer to the behavior of final purchases according to consumers, whether individuals or households that buy goods or services for personal consumption. According to Kotler and Armstrong (2014), indicators of purchasing decisions are:
1) Introduction to Needs
2) Search for Information
3) Alternative Assessment
4) Purchasing Decision
5) Post-Purchase Behavior

\section{E. Frame of mind}

The research framework describes the relationship of independent variables to dependent variables. Based 
on previous literature reviews and research, the following frame of mind was created:

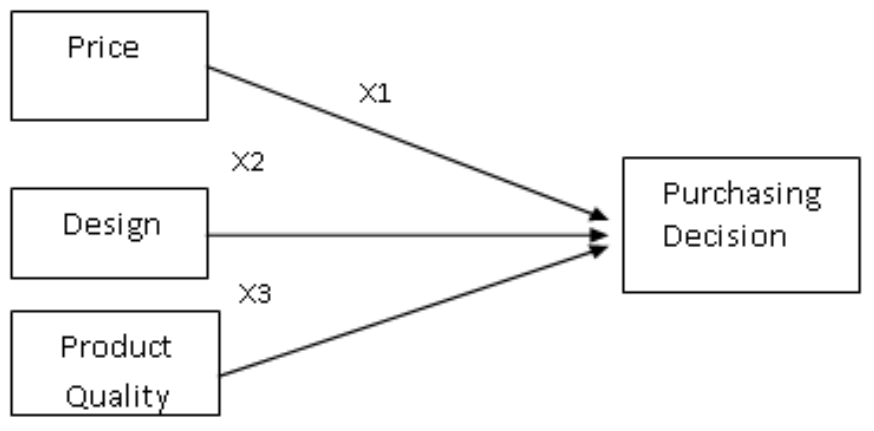

Figure 2.1 Frame of Mind

\section{F. Hypothesis}

According to sugiyono (2017), the hypothesis is defined as a temporary answer to the formulation of the research problem, where the formulation of the problem in the research has been expressed in the form of a statement. The hypothesis in this study will be spelled out as follows:

H1: Price has a significant effect on the decision to purchase cloth masks of seketeng villages

\section{Sumbawa Regency}

H2: Product design has a significant effect on the decision to purchase cloth masks in seketeng village.

\section{Sumbawa Regency}

H3: Product quality has a significant effect on the decision to purchase cloth masks in seketeng village

Sumbawa Regency

\section{A. Research Plan}

The type of research used in this study is quantitatively associative. The goal of associative research is to look at the influence of independent variables on dependent variables. The independent variables in the study were price, product design and product quality and the dependent variable was the decision to purchase a cloth mask.

\section{B. Population and Sample}

The population used in this study is the Seketeng Village community who have made purchases of cloth masks. Sampling in this study used purposive sampling methods. The determination of the number of samples is determined by using the following formula (Widiyanto, 2008: 59):

$$
n=\frac{Z^{2}}{4(M o e)^{2}}
$$

Information :

$\mathrm{n}=$ sample size

$\mathrm{z}=$ score at a certain level of significance

(The degree of freedom is determined to be $95 \%$ then $\mathrm{Z}=1.96$

Moe $=$ Margin of error, the maximum error rate is $5 \%$

$$
n=\frac{(1,96)^{2}}{4(5 \%)^{2}}=96,04=97
$$

From the results of the calculation of the formula above, the number of samples studied is 97 . To expand the sample and accuracy of the data, it became 100 respondents.

\section{Data Collection}

The method of data collection in this study was the questionnaire method. Before the questionnaire is distributed first conducted a test of research instruments, namely validity tests and reliability tests. From the results of the validity test obtained all research instruments were declared valid and reliable. The questionnaire technique is a data collection technique that is done by providing a set of written questions to respondents to be answered by research respondents, in this case, the seketeng village community who have made the purchase of cloth masks.

\section{Data Analysis}

Before the data is processed first, the classical assumption test consists of a normality test, a heteroskedasticity test, and a multicollinearity test. Data analysis techniques use multiple linear regressions. Multiple regression analysis is used to find out how much a free variable affects the bound variable. In this study, the variables are tied to 
purchasing decisions and the free variables are price, product design, and quality. The forms of multiple linear regressions in this study are as follows:

$Y=a+b_{1} X_{1}+b_{2} X_{2}+b_{3} X_{3}+e$

Information :

$\begin{array}{ll}\mathrm{Y} & : \text { Purchasing Decision } \\ \mathrm{X}_{1} & \text { : Price } \\ \mathrm{X}_{2} & : \text { Product Design } \\ \mathrm{X}_{3} & : \text { Product Quality } \\ \mathrm{a} & : \text { Parameter intercept } \\ \mathrm{b}_{1}, \mathrm{~b}_{2}, \mathrm{~b}_{3}: \text { regression coefficient } \\ \mathrm{e} & : \text { error }\end{array}$

\section{RESULT AND DISCUSSION}

\section{A. Description of data and research subjects}

1. Characteristics by gender

Based on the results regarding the characteristics of determining gender can be seen in the following table:

\begin{tabular}{|l|l|l|}
\hline Gender & Amount & Percentage \\
\hline Male & 45 & $45 \%$ \\
\hline Female & 55 & $55 \%$ \\
\hline Amount & 100 & $100 \%$ \\
\hline
\end{tabular}

Source: primary data processed 2021

It can be seen based on the table above that most research respondents are male with a percentage of 45 respondents (45\%), and the rest are female with 55 respondents with a percentage (55\%). It can be seen that most of the characteristics in the respondents were female with a total of 55 people with a percentage of $55 \%$.
2. Characteristics of respondents based on age

\begin{tabular}{|l|l|l|}
\hline Age & Amount & Percentage \\
\hline $15-25$ & 61 & $61 \%$ \\
\hline $26-36$ & 9 & $9 \%$ \\
\hline $37-50$ & 30 & $30 \%$ \\
\hline
\end{tabular}

Source: primary data processed 2021

It can be seen based on the table above that respondents aged 15-25 years as many as 61 respondents with a percentage (61\%), while respondents aged 26-36 years as many as 9 respondents with a percentage (9\%), and those aged 37-50 years as many as 30 respondents with a percentage (30\%). It can be seen that most of the respondents were aged 15-25 years with a total of 61 people with a percentage of $61 \%$.

\section{B. Classic Assumption Test Results}

1. Normality Test

Results

The normality test aims to test whether the data to be used in a normally distributed regression model or not and is worthy of use in the study is normally distributed residual data (Ghozali, 2016).

\section{One-Sample Kolmogorov-Smirnov Test}

\begin{tabular}{|c|c|c|}
\hline & & $\begin{array}{l}\text { Unstandardized } \\
\text { Residual }\end{array}$ \\
\hline $\mathrm{N}$ & & 100 \\
\hline & Mean & OE-7 \\
\hline Norm & meters $^{\mathrm{a}, \mathrm{b}}$ & \\
\hline & Std. & 2.10189842 \\
\hline & Deviation & \\
\hline & Absolute & 120 \\
\hline Most & ExtremePositive & 120 \\
\hline Diffe & & \\
\hline & Negative & -.067 \\
\hline Kolm & -Smirnov & 1.195 \\
\hline Z & & \\
\hline Asym & (2-tailed) & 115 \\
\hline
\end{tabular}

Source: primary data processed 2021 
The table above is the output of spss on the Kolmogorov-Smirnov test. From the data above, it can be seen that the value of Asymp. Sig. (2-tailed) in this study was 0.115 greater than the significance level of 0.05 . It can be concluded that the data in this study is normally distributed.

\section{Multicolonearity test.}

This test is done to find out whether in the regression model there is cholera or relationships that occur between free variables or independent variables. In a good regression model, independent variables do not collide with each other.

\begin{tabular}{|l|l|l|l|}
\hline Variable & Tolerance & VIF & Description \\
\hline Price & 0.991 & 1.009 & $\begin{array}{l}\text { There is no } \\
\text { multicollinearity. }\end{array}$ \\
\hline $\begin{array}{l}\text { Product } \\
\text { Design }\end{array}$ & 0.959 & 1.043 & $\begin{array}{l}\text { There is no } \\
\text { multicollinearity. }\end{array}$ \\
\hline $\begin{array}{l}\text { Quality } \\
\text { Product }\end{array}$ & 0.966 & 1.035 & $\begin{array}{l}\text { There is no } \\
\text { multicollinearity. }\end{array}$ \\
\hline
\end{tabular}

Source: primary data processed 2021

Based on the results above, it shows that all independent variables have a tolerance value greater than 0.10 and the VIF value is less than 10.00 so it can be concluded that all independent variables in this study do not occur multicollinearity.

\section{Heteroscedasticity Test}

The heteroskedasticity test aims to test whether in regression models there is variance inequality from residual one observation to another. If the variance from residual one observation to another remains, it is called homoskedasticity and if it is different it is called heteroskedasticity.

\begin{tabular}{|l|l|l|l|}
\hline Variable & Sig & Criteria & Description \\
\hline Price & 0.703 & 0.05 & $\begin{array}{l}\text { There is no } \\
\text { heteroskedasticity. }\end{array}$ \\
\hline $\begin{array}{l}\text { Product } \\
\text { Design }\end{array}$ & 0.858 & 0.05 & $\begin{array}{l}\text { There is no } \\
\text { heteroskedasticity. }\end{array}$ \\
\hline $\begin{array}{l}\text { Quality } \\
\text { Product }\end{array}$ & 0.097 & 0.05 & $\begin{array}{l}\text { There is no } \\
\text { heteroskedasticity. }\end{array}$ \\
\hline
\end{tabular}

Source: primary data processed 2021
Based on the results of the glejser test after the data transformation in the table above shows the significant value of all the free variables in this study is 0.05 . From this, it can be concluded that there are no symptoms of heteroskedasticity in this study variable.

\section{Multiple Linear Regression Analysis}

According to Sarwono (2013), multiple linear regression analysis is an analysis used simultaneously to examine the influence of two or more free variables on one bound variable. The general equations of multiple regressions used in this study are as follows:

$$
(\mathrm{Y}=\mathrm{a}+\mathrm{b} 1 \mathrm{X} 1+\mathrm{b} 2 \mathrm{X} 2+\mathrm{b} 3 \mathrm{X} 3+\mathrm{e})
$$

\section{Coefficients $^{\mathrm{a}}$}

\begin{tabular}{|l|l|l|}
\hline \multicolumn{1}{|c|}{ Model } & \multicolumn{2}{|c|}{$\begin{array}{l}\text { Unstandardized } \\
\text { Coefficients }\end{array}$} \\
\cline { 2 - 3 } & $\mathrm{B}$ & Std. Error \\
\hline Constant & 1.169 & 3.877 \\
Harga & .252 & .107 \\
1 & .426 & .083 \\
Desain & .283 & .087 \\
Kualitas & \\
Produk & .0821 \\
\hline
\end{tabular}

Source: primary data processed 2021

Based on the results of the multiple linear analysis above, it can be known the regression equation as follows:

$$
\mathrm{Y}=1.169+0.252 \mathrm{X} 1+0.426 \mathrm{X} 2+0.283 \mathrm{X} 3+\mathrm{e}
$$

Based on the table above there are calculations using spss value of price (X1) to purchase decision (Y) of 0.252 , design value $(\mathrm{X} 2)$ to purchase decision $(\mathrm{Y})$ of 0.426 , and product quality value (X3) to purchase decision $(\mathrm{Y})$ of 0.283 it can be explained that the regression equation obtained as follows: 
The results of the multiple regression equations above can give the following understanding:

a. Constant value

Constant value 1.169 which indicates that all independent variables (price, design, and quality of the product) are assumed to be constant or do not change then the variable value $(\mathrm{Y})$ of the purchase decision is 1,169

b. Price (X1) of purchase decision

The price coefficient value for variable $\mathrm{X} 1$ of 0.252 states that if the value of the price variable increases by one unit, then the purchase decision variable $(\mathrm{Y})$ will rise by 0.252 assuming the other free variable remains or does not change.

\section{c. Design (X2) to purchasing decisions}

The design coefficient value for variable $\mathrm{X} 2$ of 0.426 states that if the value of the price variable increases by one unit, then the purchasing decision variable $(\mathrm{Y})$ will rise by 0.426 assuming other free variables remain or do not change.

d. Product quality (X3) to purchasing decisions

The product quality coefficient value for variable $\mathrm{X} 3$ is 0.283 . This states that if the value of the price variable increases by one unit, then the purchase decision variable $(\mathrm{Y})$ will rise by 0.283 assuming the other free variable remains or does not change.

\section{Hypothesis Test}

\section{Partial Test}

According to Ghozali (2011), statistical tests show how far the influence of one explanatory or independent variable individually in explaining the variation of dependent variables and is used to determine the presence or absence of the influence of each dependent variable tested in a significant rate of 0.05 .

\section{Coefficients}

\begin{tabular}{|l|l|l|l|l|}
\hline \multicolumn{1}{|c|}{ Model } & \multicolumn{2}{|l|}{$\begin{array}{l}\text { Unstandardized } \\
\text { Coefficients }\end{array}$} & $\mathrm{T}$ & Sig. \\
\cline { 2 - 5 } & $\mathrm{B}$ & $\begin{array}{l}\text { Std. } \\
\text { Error }\end{array}$ & & \\
\hline (Constant ) & 1.169 & 3.877 & .302 & .764 \\
Price & .252 & .107 & 2.353 & .021 \\
1 & .426 & .083 & 5.137 & .000 \\
Design & .283 & .087 & 3.265 & .002 \\
\hline
\end{tabular}

Source: primary data processed 2021

Based on the table above the results of the T-test, the explanation of each variable to the purchase decision is as follows:

1) The price variable (X1) has a calculated $\mathrm{T}$ value of 2,353, meaning that $\mathrm{t}$ calculates $\geq \mathrm{t}$ table $(2,353 \geq 1,984)$ with a significance value of $0.021 \leq$ 0.05 so that it can be concluded there is a significant influence between the price and the purchase decision, then the hypothesis is accepted.

2) The design variable (X2) has a calculated $T$ value of 5,137, meaning that $\mathrm{t}$ calculates $\geq \mathrm{t}$ table $(5,137 \geq 1,984)$ with a significance value of $0.00 \leq 0.05$ so that it can be concluded there is a significant influence between the design and the purchase decision, then the hypothesis is accepted.

3) The product quality variable (X3) has a calculated $\mathrm{T}$ value of 3,256 , meaning that $\mathrm{t}$ calculates $\geq t$ table $(3,256 \geq 1,984)$ with a significance value of $0.002 \leq 0.05$ so that it can be concluded there is a significant influence between product quality and purchasing decisions, then the hypothesis is accepted.

2. Determination coefficient test (R2)

The Determination Coefision (R2) aims to determine the level of accuracy that is good in regression analysis indicated by the magnitude of the coefficient of determination (R2) between $0-1$. If the coefficient 
of determination is close to 1 it means that the independent variable has absolutely no effect on the dependent variable. If the coefficient of determination 0 means that independent variables can only provide information about dependent variables on a limited basis. The Coefficient of Determination is used to predict how much an independent variable's contribution can affect dependent variables (Ghozali, 2016).

\section{Model Summary}

\begin{tabular}{|l|l|l|l|l|}
\hline $\begin{array}{l}\text { Mod } \\
\text { el }\end{array}$ & $\mathrm{R}$ & $\begin{array}{l}\mathrm{R} \\
\text { Square }\end{array}$ & $\begin{array}{l}\text { Adjusted R } \\
\text { Square }\end{array}$ & $\begin{array}{l}\text { Std. The } \\
\text { error of the } \\
\text { Estimate }\end{array}$ \\
\hline 1 & $.579^{\mathrm{a}}$ & .335 & .314 & 2.134 \\
\hline
\end{tabular}

Source: primary data processed 2021

Based on the table above it can be seen that adjusted $\mathrm{R}$ square of 0.314 means that the influence of independent variables namely price, design, and product quality can explain the purchase decision variable $(\mathrm{Y})$ which is 0.314 or $31.4 \%$ and the remaining $68.6 \%$ is influenced by other variables outside the variables used in this study. In other words, purchasing decisions can be explained using independent variables namely price, design, and product quality of $31.4 \%$.

\section{CONCLUSION}

Based on the results of the data analyzed and the discussions that have been outlined in the previous chapter on the effect of price, design, and quality of products on the decision to buy cloth masks during the pandemic with samples used as many as 100 respondents from cloth mask users in the village. Based on the results of the study, it can be concluded as follows:

1. Prices have a positive and significant effect on the decision to purchase cloth masks during a pandemic. This shows that the price is used as one of the considerations in the decision to buy a cloth mask in Seketeng Village. This means that the more affordable the price, the higher the purchase decision on cloth masks. This condition indicates that the price suitability of cloth masks will further increase consumer purchase decisions against cloth masks during this pandemic.

2. Design has a positive and significant effect on the decision to purchase cloth masks during a pandemic. This shows that design is used as one of the considerations in the decision to buy cloth masks during the pandemic. This means that the more beautiful the appearance of the cloth mask, the higher the purchase decision on the cloth mask. This condition indicates that a good design on cloth masks it will further increase consumer purchasing decisions against cloth masks during this pandemic.

3. Product Quality has a positive and significant effect on the decision to purchase cloth masks during a pandemic. This shows that the quality of the product is used as one of the considerations in the decision to buy cloth masks during a pandemic. This means that the better the quality and durability, the higher the purchase decision on the cloth mask. This condition indicates that with good product quality in cloth masks it will further increase consumer purchasing decisions against cloth masks during this pandemic.

\section{REFERENCE}

1. Ghozali,I. (2016). Aplikasi Analisis Multivariat Dengan Program Spss. Semarang: Badan Penerbit Universitas Diponegoro

2. Kotler Dan Amstrong. (2014). Principles Of Marketing. New Jersey: Person Education Limited Kotler, P \& Kotler. (2016). Marketing Management. 15th Edition. United States: Pearson Education

3. Kotler, Keller .2012. Marketing Management, 14th, Person Education. 
4. Sarwono, Jonathan 2007, Analisis Jalur Untuk Riset Bisnis Dengan Spss, Cv. Andi, Yogjakarta

5. Pusparani, Putu Ayu Yulia Dan Ni Made Rastini. 2014. Pengaruh Kualitas Produk Dan Brand Image Terhadap Kepuasan Konsumen Dan Loyalitas Pelanggan Camera Cannon Digital Single Lens Reflex (Dslr) Di Kota Denpasar, Jurnal Administrasi Bisnis, Vol.3.No.3:1311-1319

6. Soewito, Yudhi.2013. Kualitas Produk, Merek, Desain Pengaruhnya Terhadap Keputusan Pembelian Sepeda Motor Yamaha Mio.Jurnal Ekonomi Vol.1,No.3 Juni 2013

7. Sugiyono. (2019). Metode Penelitian Kuantitatif Kualitatif Dan R\&D. Edisi Kedua Cetakan Ke-1 Bandung: Alfabeta

8. Santosa, N.A. Dkk, 2020. Desain Flyer Infografis Sebagai Sarana Sosialisasi Upaya Pencegahan Covid-19. Jurnal Lentera Widya.Vol. 2 .No 1

9. Setiadi, 2012. Perilaku Konsumen Konsep Dan Iplikasi Untuk Strategi Dan Penelitian Pemasaran. Kencana. Jakarta.

10. Tjiptono, Fandy. (2014). Pemasaran Jasa. Andi.Yogjakarta

11. Widiyanto, Ibnu. 2008. Pointers: Metodologi Penelitian. BP Undip, Semarang.

12. Yuliana.(2020). Corona virus diseases(Covid19); Sebuah tinjauan Literatur. Jurnal Wellness And Healtymagazine Volume 2, No 1

\section{Cite this article as :}

Fendy Maradita, Reza Muhammad Rizqi, Gustiawan, "Price, Design, and Quality of Products in Influencing the Decision to Purchase Cloth Masks During the Covid 19 Pandemic", International Journal of Scientific Research in Science and Technology (IJSRST), Online ISSN : 2395-602X, Print ISSN : 23956011, Volume 8 Issue 6, pp. 455-463, NovemberDecember 2021. Available at doi : https://doi.org/10.32628/IJSRST218667 Journal URL : https://ijsrst.com/IJSRST218667 